\title{
Taxonomic affiliation influences the selection of medicinal plants among people from semi-arid and humid regions - a proposition for the evaluation of utilitarian equivalence in Northeast Brazil
}

\author{
Rafael Reinaldo ${ }^{1}$, Ulysses Albuquerque ${ }^{2}$, Patrícia Medeiros ${ }^{\text {Corresp. } 3}$ \\ 1 Departamento de Biologia, Universidade Federal Rural de Pernambuco, Recife, Pernambuco, Brazil \\ 2 Centro de Biociências, Universidade Federal de Pernambuco, Recife, Pernambuco, Brazil \\ 3 Campus de Engenharias e Ciencias Agrárias, Universidade Federal de Alagoas, Rio Largo, Alagoas, Brazil \\ Corresponding Author: Patrícia Medeiros \\ Email address: patricia.medeiros@ceca.ufal.br
}

Background: This study sought to investigate the occurrence of taxonomic patterns between semi-arid and humid regions, verifying how the taxonomic affiliation can influence the selection of plants for medicinal purposes and act as a selection criterion.

Methods: Taxonomic affiliation and the selection of medicinal plants relationship with four different communities was analyzed, two of them associated with a seasonally dry tropical forest and the other two associated with a tropical rain forest. We used the Utilitarian equivalence model (transposing the concept of ecological equivalence, proposed by Odum, for ethnobotany) to test the hypothesis that species that have the same taxonomic affiliation tend to have the same therapeutic applications in different environments (Utilitarian equivalence). In addition, we use the Utilitarian redundancy Model to verify whether, within the same medical system, plants of the same taxonomic affiliation tend to be redundant (treating the same diseases).

Results: We found that a pair of plants of the same genus were 9.25 times more likely to be equivalent than a different genus pair ( $O R=9.25$, IC 1.68-51.02, $p<0.05)$. When we analyzed the species used by the same population, the chances of a pair having similar therapeutic uses (Utilitarian redundancy) increased when they were species of the same family (OR $=1.94, I C 1.06-3.53 ; p<0.05)$.

Conclusions: These findings confirm the hypothesis that there is an influence of taxonomic affiliation, in terms of genera and family, on the selection of medicinal plants in semi-arid and humid areas in Northeast Brazil. In addition, our Utilitarian equivalence model can be an important tool in the search for more common selection criteria, in order to identify the shared characteristics among the equivalent pairs and consequently the main types of perceptions or stimuli that led to the inclusion of such species in local pharmacopoeias. 


\section{Taxonomic affiliation influences the selection of}

2 medicinal plants among people from semi-arid and

3 humid regions - a proposition for the evaluation of

4 utilitarian equivalence in Northeast Brazil

5

6

7

8

9

10

11

12

13

14

15

16

17

18

19

20

21

22

23

24

25

26

27

28

29

30

31

32

33

34

35

36

37

38

Rafael Reinaldoํㅡㄴ Ulysses Albuquerque ${ }^{2}$, Patrícia Medeiros*3

${ }^{1}$ Departamento de Biologia. Universidade Federal Rural de Pernambuco, Recife, Brazil.

${ }^{2}$ Centro de Biociências, Universidade Federal de Pernambuco, Recife, Pernambuco, Brazil.

${ }^{3}$ Campus de Engenharias e Ciências Agrárias, Universidade Federal de Alagoas, Rio Largo, Alagoas, Brazil.

Corresponding Author:

Patrícia Muniz de Medeiros ${ }^{2}$

BR 104, s/n, Mata do Rolo, Rio Largo, Alagoas, 57100-000, Brazil.

Email address: patricia.medeiros@ceca.ufal.br

\section{Abstract}

Background: This study sought to investigate the occurrence of taxonomic patterns between semi-arid and humid regions, verifying how the taxonomic affiliation can influence the selection of plants for medicinal purposes and act as a selection criterion.

Methods: Taxonomic affiliation and the selection of medicinal plants relationship with four different communities was analyzed, two of them associated with a seasonally dry tropical forest and the other two associated with a tropical rain forest. We used the Utilitarian equivalence model (transposing the concept of ecological equivalence, proposed by Odum, for ethnobotany) to test the hypothesis that species that have the same taxonomic affiliation tend to have the same therapeutic applications in different environments (Utilitarian equivalence). In addition, we use the Utilitarian redundancy Model to verify whether, within the same medical system, plants of the same taxonomic affiliation tend to be redundant (treating the same diseases).

Results: We found that a pair of plants of the same genus were 9.25 times more likely to be equivalent than a different genus pair $(\mathrm{OR}=9.25$, IC $1.68-51.02, \mathrm{p}<0.05)$. When we analyzed the species used by the same population, the chances of a pair having similar therapeutic uses (Utilitarian redundancy) increased when they were species of the same family (OR $=1.94$, IC 1.06-3.53; $\mathrm{p}<0.05)$.

Conclusions: These findings confirm the hypothesis that there is an influence of taxonomic affiliation, in terms of genera and family, on the selection of medicinal plants in semi-arid and humid areas in Northeast Brazil. In addition, our Utilitarian equivalence model can be an 
important tool in the search for more common selection criteria, in order to identify the shared characteristics among the equivalent pairs and consequently the main types of perceptions or stimuli that led to the inclusion of such species in local pharmacopoeias.

Keywords: ethnopharmacology, traditional knowledge, use patterns, selection criteria, ethnobotany.

\section{Introduction}

Local plant-based medical systems, which include the whole set of knowledge, beliefs and practices to deal with diseases, with plants as a main material constituent, have been studied as a model to better understand the relationship between people and natural resources $[1,2,3,4]$. Considering that human behavior on plant use depends on biological, sociocultural and environmental factors, an increasing concern among ethnobotanists is to clarify how these factors act and interact generating use patterns. In this sense, many advances in ethnobotany included the development of techniques, methods and hypotheses based on the theoretical framework of ecology, adapting ecological models to the scenario of complex interactions between biology and culture [see 5].

The Utilitarian redundancy Model (URM), for example, started from ecological redundancy and was originally created with the purpose of explaining how the existence of botanical species with high overlapping uses can contribute to the maintenance and resilience of a given Local Medical System [5; 6]. The main assumption of URM, already demonstrated in empirical studies, is that redundant species assure the functions of the system in the absence of other species that have the same function [see 7].

Another important proposition is the ecological apparency hypothesis that, in the context of ethnobotany, explains the high amount of herbaceous plants in local pharmacopoeias because of the existence of strongly bioactive qualitative compounds [8]. These and other recent propositions differ from the old quantitative approaches because they assume that socioecological systems and conventional ecosystems are governed by some variables that are common to them, especially the influence of the environment, as some empirical studies have shown [see 9]. Despite notable theoretical advances, there are still gaps, especially regarding the similarities and differences between medical systems.

The Local Medical Systems of different peoples around the world have dynamics and structures that, directly or indirectly, reflect the different cultural traits of a given human population [10]. In this sense, people with distinct cultural origins could present significant differences in the mode of selection of medicinal plants [10]. However, there is also evidence that two distinct human cultures, living far apart but inserted in similar environments, tend to select medicinal plants in a similar way, as there would be a strong positive correlation between the medicinal flora and the floristic environment [11]. In other words, similarities as to the diversity of plant species available may lead to similarities in medicinal systems [11].

Given this duality between culture and the environment, some studies on the medicinal flora of different regions of the world have been demonstrating certain patterns of use. They are 
suggesting that, even when medicinal floras are essentially composed of different species, plants used for the same purposes tend to share common traits, such as the same taxonomic group [12, $13,3]$.

One of the most interesting models to understand how environmental and cultural aspects can guide local systems is the study of the therapeutic use of plants in various human groups [14]. In addition, a good scenario to study the behavior of medicinal plants is the study of essentially different environments, comparing, for example, humid environments vs. arid environments [15], considering that, if certain use behaviors persist even among areas that suffer different environmental pressures, these can be a pattern of behavior. Although the present study follows a similar approach to those discussed above, it is proposed to use the concept of Utilitarian equivalence, a new framework, based on Odum's [16] ecological equivalence model, which aims to better understand cases of overlap uses between medicinal floras from different regions.

\section{Ecological Equivalence}

This study considers the concept of ecological niche, one of the central elements of ecology. In the words of Begon et al. [17] ecological niche corresponds to "the ways in which tolerances and requirements interact to define the conditions and resources needed by an individual or species to practice their way of life". In other words, it is the multidimensional role of a species or an individual in the functioning of a given ecosystem [18]. In this sense, it was suggested by Odum [16] that "organisms that occupy the same ecological niches or similar ecological niches in different geographic regions..." could be called ecological equivalents. Odum also points out that "species that occupy equivalent niches tend to be closely related from a taxonomic point of view, although often they are not in regions that are very separate or isolated from one another" [16].

For Odum [16] distinct biogeographic regions presuppose "species composition of quite different communities". Where there are physically similar habitats, similar ecosystems develop [16]. Thus, "functional niches are occupied by equivalent biological groups, regardless of the composition of the fauna and flora of the region" [16]. From this perspective, we can consider, for example, that a prairie ecosystem will occur in any region of the world that has a prairiefriendly climate, with local native species being organized to occupy available niches [16].

Odum [16] highlighted ecological equivalents in three trophic niches of four coastal regions and presented similar herbivorous littorina belonging to the same genus, thus reinforcing the idea that ecological equivalence may undergo taxonomic influence. Some empirical evidence on the subject can be found in Fišer et al. [19]. When considering ideas similar to those of Odum, Fišer et al. [19] evaluated the overlap level of niches between cryptic species of crustaceans of the genus Niphargus and their results suggest that, on a regional scale, the species play equivalent ecological roles, which in turn may be related to a still recent speciation process [19]. In light of the mentioned above, the equivalence model can help to examine if, in a 
118 similar way, the occurrence of species in different regions with high overlapping of medicinal

119 use is due to similarities between them, thus allowing to elucidate aspects of the selection of

120 medicinal species.

121

122

123

124

125

126

127

128

129

130

131

132

133

134

135

136

137

138

139

140

141

142

143

144

145

146

147

148

149

150

151

152

153

154

155

156

157

\section{Utilitarian equivalence}

The present study transposes for ethnobotany a concept analogous to that of ecological equivalence, hereafter called Utilitarian equivalence, and uses it as an analytical tool in the search for common criteria for the selection of medicinal plants by people in semi-arid and in humid regions in the Northeast of Brazil. This proposition is based on the understanding that access to equivalent medicinal species provides the ideal scenario to seek common selection criteria, in order to identify the shared characteristics among the equivalent pairs and consequently the main types of perceptions or stimuli, which led to the inclusion of such species in local pharmacopoeias.

The term Utilitarian equivalence, here proposed, indicates species that are used for the same purposes or similar purposes in different socioecological systems. In this study, we used local medical systems as a model. However, the term is not restricted only to the therapeutic use of plants, and this approach can be directed to the diverse applications that any biological resources will receive from human groups.

Our model is based on the assumptions that: a) Utilitarian equivalence, understood as the high overlap of use between two species in distinct socioecological systems, is relative and not absolute, since, in the absence of intrinsically identical plant species or culturally equal peoples, the medicinal uses are not necessarily identical, but rather similar; b) equivalence is due to two groups of complementary variables, cultural traits and environmental factors; c) the evolutionary events that led to Utilitarian equivalence may be associated with the similarity between intrinsic characteristics of useful species.

\section{Is Utilitarian equivalence the same as Ethnobotanical Convergence?}

The concept of Utilitarian equivalence proposed here is different from the concept of Ethnobotanical Convergence presented by Garnatje et al. [20]. Although both deal with different species used for the same purposes, the first has as its central element the overlap of uses between species of different medical systems. The concept of 'Ethnobotanical Convergence' is different from that of Utilitarian equivalence, especially since it is restricted to "similar uses for plants included in the same node of a phylogeny" [20]. Thus, a high overlap of medicinal uses between phylogenetically distant plants, such as a fern in Africa and an angiosperm in North America, can be considered a case of Utilitarian equivalence, but not of 'Ethnobotanical Convergence'. On the other hand, if the Ethnobotanical Convergence is established between species of different Local Medical Systems, there is also Utilitarian equivalence.

The concept of Utilitarian Equivalence is also different from the concept of Ethnobotanical Convergence from Hawkins and Teixidor-Toneu et al. [21]. The authors reviewed the idea of Garntaje et al. [20] and proposed an adjustment that considered the accepted 
158

159

160

161

162

163

164

165

166

167

168

169

170

171

172

173

174

175

176

177

178

179

180

181

182

183

184

185

186

187

188

189

190

191

192

193

194

195

196

197

meaning of the term convergence, indicating that Ethnobotanical Convergence should be only used in cases where the independent discovery of the medicinal potential is evident. Therefore, it does not apply to cases of overlapping uses that are a consequence of the diffusion of knowledge among different peoples [21]. This distinction is important because one of the main applications of studying Ethnobotanical Convergence is bioprospecting. Therefore, closely related plants that are used by different populations for the same end may have similar chemical characteristics that justify such convergence [21].

In the case of Utilitarian Equivalence, it can be used in the search for environmental or cultural selection criteria. Therefore, taxonomy is only one possible driver of Utilitarian equivalence, but other aspects such as a plant's habit, flavor or availability may play important roles in such process. Furthermore, since our concept does not require independence of the studied human populations, any taxonomic patterns found may be due to (1) shared chemical characteristics of closely related plants, or (2) cultural diffusion leading to attribution of similar uses to closely related plants because of their morphological similarity.

Finally, convergence is established when closely related plants share individual uses (e.g. a single therapeutic indications or categories of conditions). As for Utilitarian Equivalence, it is only established when two species have a substantial overlap of uses. Following this perspective, the present study tried to test the following hypotheses:

1) In distinct medical systems, taxonomically close species tend to present Utilitarian equivalence. It was expected that pairs of species with the same taxonomic affiliation, in terms of genus and/or family, would be more likely to be utility equivalents than taxonomically distant plants.

2) Within a medical system, taxonomically close species tend to present Utilitarian redundancy.

It was expected that pairs of species having the same taxonomy in terms of genus and/or family would be more likely to be utility redundant than taxonomically distant plants.

\section{Materials \& Methods}

\section{Study area}

Within the purpose to verify if certain use behaviors persist even between areas with different floristic compositions and social-ecological contexts, also minimizing the probability of results being skewed by knowledge transmission, it was decided to test the Utilitarian equivalence model among communities inserted in two areas from different ecosystems and essentially distinct and distant from each other. In this sense, the study was conducted in four rural communities, two neighboring communities in an area in a Tropical Rainforest (TR), in a hot and humid climate region, and two neighboring communities in a seasonally dry tropical forest area (SDTF), in a hot and dry climate region with semi-arid regime, all located in the Northeast of Brazil.

We chose to compare different ecosystems because we intended to evaluate if, even under completely different social-ecological conditions, some taxonomic patterns on plant use could emerge. Therefore, these communities may not be seen as replicates, but rather as case- 
198

199

200

201

202

203

204

205

206

207

208

209

210

211

212

213

214

215

216

217

218

219

220

221

222

223

224

225

226

227

228

229

230

231

232

233

234

235

236

237

studies. Additionally, our choice for including more than one community in a single region was also not related to the production of replicates. We did not compare neighboring communities, as our intention was to consider them as a continuum. Thus, we adopted a meta-community approach, since, for both cases, we chose neighboring communities.

\section{Tropical Rainforest}

The Murici Ecological Station (ESEC-Murici), a large forest fragment located in the municipality of Murici-Alagoas - Northeast of Brazil, $60 \mathrm{~km}$ from the state capital, Maceió, represented the Tropical Rainforest Area, locally named the Atlantic Forest. The surrounding environment is basically composed of areas of sugar cane cultivation, although there are also other interface situations such as cattle raising and eucalyptus plantation. The vegetation is considered Dense Ombrophylous Forest and has an area of 6.116 ha [22]. The region presents a humid to subhumid tropical climate, with two well-defined seasons: dry summer, which runs from September to March and rainy winter, which runs from April to August [22]. The climate of the region is type As, according to Köppen classification, with rainfall totals ranging from 800 to $1800 \mathrm{~mm}$ and average temperature of $25^{\circ} \mathrm{C}$ [22]. Near the forest, there is a predominantly agricultural human population that exploits forest resources for survival [22].

The rural communities located in the Atlantic Forest were the Dom Helder Câmara settlement and the Che Guevara settlement, both belonging to the municipality of Murici/Alagoas (S $9^{\circ} 18$ ' $26^{\prime \prime} \mathrm{W} 35^{\circ} 55^{\prime} 55^{\prime \prime}$ ). A total of 204 people live in the settlement Dom Hélder Câmara, while the Settlement Che Guevara has 220 residents. Local populations are mainly made up of former landless laborers whose main occupation was planting sugarcane on rural properties in surrounding municipalities, and settled in the settlements around the year 2000, when the areas were made available for agrarian reform ${ }^{1}$ [23]. Although there is a low level of education among adults, each of the communities has a municipal public school offering basic education. In addition, there is regular school transportation for students who attend high school in public schools in the urban area. Hospitals and health posts are restricted to the urban area [24], distant approximately $13 \mathrm{~km}$ from the community. Even with the possibility of access to health care by school transports and similar means, it is possible to note that part of the local population remains resistant to medical consultations and exhibits a rich traditional medicinal repertoire based mainly on plant species.

As for religious aspects, the majority of the population of the settlements Dom Helder Câmara and Che Guevara is adept to Christian Religious Doctrines. However, in both communities it is also possible to observe healing practices originating from religions of African and indigenous matrices oriented towards magic-religious use involving the use of plants.

\section{Seasonally Dry Tropical Forest}

The area of the seasonally dry tropical rainforest selected, locally known as the Caatinga, was the Catimbau National Park (PARNA Catimbau), an Integral Protection Conservation Unit, created by a decree on 13 of December 2002. The park has about 62,000 hectares and is located 
238 in the municipalities of Ibirimirim, Tupanatinga and Buíque in the state of Pernambuco, 295

239 kilometers from Recife, the state capital. Although it is a permanent conservation area, forest

240 areas are not continuous, with vegetation patches dominated by shrubs or herbaceous plants,

241 which is probably related to a degradation process caused by chronic disturbances due to

242 antrophic activities [25] The park is located in the transition zone between the agreste and the

243 sertão, and presents a Bsh climate according to the classification of Köppen [26], with transition

244 to tropical humid, with rainfall ranging from 650 to $1100 \mathrm{~mm}$.

245 The two communities in the seasonally dry tropical rainforest region were Igrejinha and

246 Batinga, both belonging to the municipality of Buíque - Pernambuco - Northeast of Brazil (S

$\left.247 \quad 08^{\circ} 37^{\prime} 23^{\prime \prime} \mathrm{W} 37^{\circ} 09^{\prime} 21^{\prime \prime}\right)$. Approximatelly 171 and 91 people inhabit the communities of

248 Igreginha and Batinga, respectivelly. The population of both communities carry out subsistence

249 agriculture and has a close dependence on plant and animal species native to the region, both for

250 food and for medicinal purposes. The vast majority of the population did not attend schools,

251 especially the older population. However, both communities have primary schools. Most of the

252 inhabitants have always lived in the communities where they now live, having a long and close

253 relationship with the native vegetation.

254 The Igrejinha community has only one church that is Protestant, and just as in the 255 communities described above, most people are adept of Christian Religious Doctrines. On the

256 other hand, the inhabitants of the Batinga community affirm they are descendants of indigenous 257 peoples and perform various healing and magico-religious rituals that rely on the use of plant

258 species. The nearest Hospitals and health posts are restricted to Catimbau Village, an urban area 259 that is about $20 \mathrm{~km}$ away. Access is possible from private vans who make the transfer at certain 260 times of the day. Access to health services is difficult and part of the population prefers to treat 261 themselves with medicinal plants.

262 The criteria for choosing the communities studied included: 1) rural communities; 2)

263 have a minimum distance of $10 \mathrm{~km}$ in the urban environment; 3 ) are located close to native 264 vegetation, at a distance of $1 \mathrm{~km}$ from the forest environment.

265

266

267

268

269

270

271

272

273

274

275

276

277

\section{Ethnobotanical Survey}

The ethnobotanical survey took place between January 2017 and January 2018 (on average 15 days a month) and included the selection of informants and semi-structured interviews (supplemental file 1). Given the need to obtain a reliable sample of the medicinal repertoire of the communities, we chose to carry out a non-probabilistic selection of informants, recruiting only locally legitimated people and recognized as knowledgeable about medicinal plants (table 1). In this stage, the Snowball method [27] was used, which consisted of asking a local medicine specialist to indicate the specialists they knew. The same process was performed with the others until the indicated names repeated. Participants younger than 18 years were not included.

With each informant, a semi-structured interview was carried out in association with the free-listing method [28] in which the interviewees were asked about the medicinal plants they 
278 knew, thus generating an initial list with the names of the plants used. For each ethnospecies

279 (ethnobiological taxonomic category based on local communities' classifications) mentioned, the 280 following question was asked: Is this plant important in the treatment of health problems? The

281 information obtained was recorded field notebooks and forms.

282

283

Table 1. Distribution of local experts interviewed by community and by sex.

284

285

\section{Collection of botanical material and taxonomic identification}

286

287

For the taxonomic identification of the mentioned species and validation of the popular names attributed to the respective plants, guided tours were performed in forest areas commonly 288

289 frequented to collect the medicinal plants. In the guided tour method, at least one member of the community with extensive knowledge of the local flora and the study area is invited to identify

290

291

292 within the forests the listed ethnoespecies [29]. Two informants from each community were selected for each collection, using as criteria the highest amounts of plants cited by each informant.

293

294

The identification of the species collected was performed by the Instituto Agronômico de

295

296

297

298

299

300

301

302

303

304

305

306

307

308

309

310

311

312

313

314

315

316 Initial selection of therapeutic and species indications: inclusion and exclusion criteria

\section{Ethical and legal aspects}

Pernambuco (IPA), and was based on the APG IV classification system [30]. The control material was deposited in the IPA Herbarium. One point to be highlighted is that not all the ethnospecies mentioned could be collected and/or identified, mainly due to seasonality or the rarity/absence of the species in the region. When this happened, the species (in this case, ethnospecies) was excluded from the analyzes.

An authorization for scientific activities in the Catimbau National Park area (PARNA Catimbau) was requested from Instituto Chico Mendes de Conservação da Biodiversidade (ICMBio/SISBIO), an agency linked to the Brazilian Ministry of the Environment (MMA), for the collection of botanical material (authorization number 67801-1). In addition, the present study was approved by the Human Research Ethics Committee (CEP) of the Universidade Federal de Pernambuco under the authorization number 30919514.9.0000.5207, following resolution 466/2012 of the National Health Council in Brazil. In accordance with this resolution, the informants who agreed to participate in the study were asked to sign the Informed Consent Form, through which they authorized the application of forms and interviews, as well as the publication of the data obtained.

\section{Data processing}

The data obtained from the semi-structured interviews were filtered (Supplemental file 2) by inclusion and exclusion criteria described below. 
This study considered only the therapeutic indications cited by two or more people in a given region. For example, if the plant 'A' of the Seasonally Dry Tropical Forest was assigned only 'analgesic' and 'cancer treatment' uses and this information was cited by a single informant, this information was disregarded and consequently plant A was excluded from the analyzes. Similarly, if in a given region none of the information on how to treat a particular disease was shared by two or more informants, the disease was excluded from the study. This procedure was designed to prevent idiosyncratic information from biasing results and conclusions.

\section{Secondary selection of species and therapeutic indications: inclusion and exclusion criteria}

This study was conducted under an etic approach, that is guided by the researcher's perspective. In this context, only the mentions of diseases and symptoms accepted within the scope of conventional medicine were analyzed. After initial selection of therapeutic indications and species, only indications that remained in both the Seasonally Dry Tropical Forest and the Tropical Rain Forest were included. This consequently led to the exclusion of plant species that dealt only with the disregarded diseases.

By accounting for the information that fit the inclusion criteria defined herein, we had 27 therapeutic indications and 64 plant species, seven of which are listed in both the Atlantic Forest and the Caatinga (table 2). The study considered both native and exotic species.

Table 2. Taxonomic affiliation, therapeutic indications and popular names of the 64 species obtained from the local experts of each phytophysiognomic region (Seasonally Dry Tropical Forest and Tropical Rainforest).

\section{Data analysis}

The identification of utility equivalents and utility redundancies between the Caatinga and Atlantic Forest areas was performed through a similarity analysis (Jaccard). A binary matrix was constructed by gathering data from the interviews, setting the plants as objects and the therapeutic indications as descriptors. When a plant was used for a given therapeutic indication, the cell was filled with value 1 . When a plant was not used for a given therapeutic indication, the corresponding cell had the value zero. In relation to Utilitarian equivalence, the analysis now considered the pairs formed by plants of the same species, in cases in which the same species occurred in both regions, sometimes not considered. When considering pairs of the same species, the objective was to verify if plants that include the same biological entity, and that naturally share common traits, contribute to a scenario of overlapping medicinal uses among taxonomically close plants.

Still, when the same botanical species was mentioned in the two regions, it entered the matrix as two distinct entities (Plant A - Atlantic Forest and Plant A - Caatinga). Based on the binary matrix, the Jaccard similarity matrix was constructed. Pairs of plants with more than 50\% 
357

358

359

360

361

362

363

364

365

366

367

368

369

370

371

372

373

374

375

376

377

378

379

380

381

382

383

384

385

386

387

388

389

390

391

392

393

394

395

of similarity were registered and classified as 'redundant' (when they were plants from the same region) and 'equivalents' (when they were plants from different regions).

For the analysis of the influence of taxonomic affiliation in favor of the establishment of Utilitarian equivalence and Utilitarian redundancy among the botanical species, the odds ratio test (OR) was used, which is more indicated when there are small values, since the amount of pairs was much lower than the number of non-equivalent pairs. The OR tested:

1) if pairs formed by plants of the same genus are more likely to be equivalent; 2) if pairs formed by plants of the same family are more likely to be equivalent; 3 ) if pairs formed by plants of the same genus are more likely to be redundant; 4) if pairs formed by plants of the same family are more likely to be redundant.

The $p$ value for each test was calculated by testing the null hypothesis of independence between the genus/family variables and the Utilitarian equivalence. The same approach was used to test the relationship between genus/family variables and Utilitarian redundancy. The odds ratio calculations were performed by the oddsratio function of the fmsb package available in the statistical program R, version 3.2.2 (The R Foundation for Statistical Computing). For the processed tests, $\mathrm{p}<0.05$ was considered.

\section{Results}

Analysis of the influence of the taxonomic affiliation in favor of the establishment of Utilitarian equivalence and Utilitarian redundancy

The species cited by more than one local expert in each area are shown in table 2 . The results of the analyzes that did not consider pairs of the same species (table 3) showed that the chances of a pair being utility equivalent increased when they were species of the same genus $(\mathrm{OR}=9.25$, CI 1.68-51.02, $\mathrm{p}<0.05)$. The family variable was not significant, although the $\mathrm{p}$ value was close to $0.05(\mathrm{OR}=1.87, \mathrm{CI}=0.92-3.80, \mathrm{P}=0.08)$. However, when the analyzes also considered the pairs formed by the same botanical species mentioned in both regions (table 4), the chances of pairs of the same family being equivalent increased a lot. The family variable was significant $(\mathrm{OR}=2.7, \mathrm{CI} 1.49-4.88, \mathrm{p}<0.001)$ and the genus variable also remained significant, however with an even higher $\mathrm{OR}$ value $(\mathrm{OR}=11.77$, CI 4.48-30.93; $\mathrm{p}<0.0001)$. Although this last finding does not fit the concept of Utilitarian equivalence, because it is the same taxonomic entity, it supports the idea that plants used for the same ends share common traits. Following this rationale, we also chose to discuss this finding. These results confirm the hypothesis that there is influence of the taxonomic affiliation on the establishment of Utilitarian equivalence (see table 4).

In the case of Utilitarian redundancy, there was no positive correlation between the genus variable and the Redundancy establishment $(\mathrm{OR}=2.21$, CI $0.27-17.79, \mathrm{p}=0.44)$. On the other hand, the chances of a pair being redundant increased when they were species of the same family $(\mathrm{OR}=1.94, \mathrm{CI} 1.06-3.53, \mathrm{p}<0.05)$. These results confirm the hypothesis that there is influence 
396

397

398

399

400

401

402

403

404

405

406

407

408

409

410

411

412

413

\section{Discussion}

415

416

417

418

419

420

421

422

423

424

425

426

427

428

429

430

431

432

433

434

435 (see table 5). Utility Equivalents. Utility Equivalents. described [30].

of the taxonomic affiliation, in terms of family, on the establishment of Utilitarian redundancy

Table 2. Taxonomic affiliation, therapeutic indications and popular names of the 64 species obtained from the local experts of each phytophysiognomic region (Seasonally Dry Tropical Forest and Tropical Rainforest).

Table 3. Equivalence without pairs of the same species: results of the odds ratio test that verified whether pairs formed by plants of the same genus or of the same family are more likely to be

Table 4. Equivalence with pairs of the same species: results of the odds ratio test that verified whether pairs formed by plants of the same genus or of the same family are more likely to be

Table 5. Results of the odds ratio test that verified whether pairs formed by plants of the same genus or the same family are more likely to be Utility Redundants.

\section{There are more chances of there being Utilitarian equivalence among pairs that include species of the same genus}

The prediction that local experts from the different regions, Atlantic Forest and Caatinga, have great chances of selecting the same genus or the same botanical family to treat similar diseases was confirmed, indicating that knowledge production in plant-based medical systems is influenced by intrinsic characteristics of the botanical species. There are indications in other countries that the selection of medicinal plants suffers this type of taxonomic influence. SaslisLagoudakis et al. [3], for example, analyzed the medicinal flora of three distinct regions, Cape region (South Africa), Nepal and New Zealand, and found a close phylogenetic proximity between species used to treat similar diseases.

In addition, worthy of note is the study by Molander et al. [31], which addressed the treatment of venomous snake bites and analyzed the local medicinal flora of Brazil, Nicaragua, Nepal, China and South Africa. As a result, families Apocynaceae, Lamiaceae and Rubiaceae performed as overused groups in at least two of the five countries. In addition, analyzes at the genus level have shown that the Piper L. group was overused in at least two of the countries

The obvious patterns in terms of convergence of medicinal uses among taxonomically close plants are probably related to the sharing of secondary compounds among species of the same taxonomic group [31]. In a study comparing the botanical genera of Peru and Mali, Bletter [32] found that the genera present in both countries were used for the same medicinal purposes. Since it is difficult to disseminate knowledge among the peoples of the two regions, given the 
436

437

438

439

440

441

442

443

444

445

446

447

448

449

450

451

452

453

454

455

456

457

458

459

460

461

462

463

464

465

466

467

468

469

470

471

472

473

474

475

geographic distance and the absence of historical relations between the two areas, it is more likely that the different peoples have reached the same conclusions about the use of plants independently, that is, evolutionary convergence [32].

If, on the one hand, the chemical efficacy provided by the chemical repertoire of each botanical family can explain the Utilitarian equivalence among taxonomically close plants, this does not exclude the possibility that, processes of knowledge transmission among peoples of different regions may have contributed to the formation of the observed scenario. If we consider that 14 out of the 64 species analyzed are not native to Brazil (12 in the FTSS and 5 in the FTU), with most of these exotic species coming from the Old World, it is probable that the diffusion of knowledge of use is among the factors underlying the incorporation of these plants into local medical systems.

Some local medical systems in Northeast Brazil also carry a strong influence of African cultural matrices, due to a regime of slavery that brought Africans to the country, but especially to that region [33]. It should be noted that Albuquerque [34] investigated cases of substitution of medicinal species of the same genus, Ocimum L. (Lamiaceae), carried out by Africans when they arrived in Brazil, and concluded that the substitution process obeyed morphological similarities, namely plant, type of inflorescence and fruit [34]. In addition, pharmacological studies demonstrate that many of these substitute species have the same biological activity observed for African medicinal species of this genus [34]. Therefore, utilitarian equivalence cases may be related to both historical knowledge of a past social group and chemical similarities between equivalent plants.

\section{Utilitarian redundancy between two species is associated with their taxonomic affiliations}

Our findings also demonstrated that the Utilitarian redundancy among botanical species may be associated with their taxonomic affiliations in terms of family. As discussed in the case of equivalence, taxonomic proximity may imply the sharing of other traits such as the presence of certain classes of chemical compounds [35] and thus Utilitarian redundancy may also emerge from the similarity of the chemical repertoires of certain plants. Some studies have inferred on the chemical influence on the configuration of redundancy scenarios. In a study in the Caatinga area, Santoro et al. [7] dealt with the factors underlying the process of choosing and incorporating medicinal plants with the same therapeutic indications and found that most of the diseases considered to be more serious are not very redundant (they have few plants that can treat them). One explanation for this scenario is that more serious diseases may require more specific treatments, requiring chemical compounds restricted to certain plants, whereas less serious diseases allow treatment from a wider spectrum of chemical compounds found in several plants $[7,36]$.

Although Santoro et al. [7] have not performed chemical analyzes to demonstrate this interpretation, there is evidence of the importance of phylogeny for character distribution responsible for certain pharmacological activities. Rønsted et al. [35], for example, have shown a correlation between phylogenetic proximity and the diversity and inhibitory activity of alkaloids 
476 to the enzyme acetylcholinesterase (AChE). In this sense, the selection of redundant plants from

477 the same family would be partly explained by the sharing of an evolutionary past that culminated

478 in similarities in terms of biosynthetic pathways responsible for secreting compounds of

479 medicinal value [35].

480 Another way to approach the influence of taxonomic affiliation on the Utilitarian

481 redundancy scenario is that the local population of each region studied may be selecting

482 medicinal plants based on certain cultural traits and local perceptions of their own. Knowing that

483 plants of the same family tend to share the same classes of chemical compounds [32], and that

484 these compounds are responsible for the organoleptic characteristics [37], it is possible that

485 flavor and odor characteristics serve as clues for selection of species for the treatment of certain

486 diseases. Thus, the Arecaceae family, widely represented in the medicinal repertoire of several

487 peoples [1], may be selected based on its bitter taste, since it has a great variety of sesquiterpenes

488 and other bioactive compounds, whose taste is bitter [37]. Thus, cultural factors should also be

489 considered for a broader understanding of the taxonomic influence on Utilitarian redundancy.

490

491

492

493

494

495

496

497

498

499

500

501

502

503

504

505

506

507

508

509

510

511

512

513

514

\section{Limitations and prospects}

One of the limitations of this study is the dynamic nature of the taxonomic classifications that guided our statistical analyzes. Considering the changes in the taxonomic groupings over the decades, which will undoubtedly still occur to some extent in the coming years, we consider that the conclusions regarding our model need to be minimally relativized. However, there are arguments in favor of using the family and genus categories in studies of this type. According to Evert and Eichhorn [38], the association between molecular systematics and the study of morphological characters has brought greater reliability to the use of these taxonomic categories. The authors also state that almost all families of flowering plants currently occupy a wellsupported phylogenetic position, and this is progressing well at the genus level. Besides, even the oldest studies, based on outdated classifications (based on external similarities), allowed relevant advances in terms of medicinal plant use patterns [See 1].

It is also worth explaining that although we conducted this study in four communities, our small sample size may have influenced results. Our decision to consult only local specialists in medicinal plants, with a non-probabilistic sampling, and to exclude idiosyncratic information, led to a considerable reduction in the sample size for both interviewees and plants. Regarding the limited number of informants, our results may not be generalized for the whole communities but rather understood as a product of local experts' knowledge and behaviors.

Concerning our limited number of species, since the main objective of this study is to recognize use patterns, we believe that adding idiosyncratic knowledge to the analysis could produce "noises" in the database and, consequently, decrease our explanatory power. Since we are dealing with tendencies, individual information would not be useful to our research design. However, future studies would gain by increasing the number of communities and (consequently) interviewees and plant species, making statistical procedures even more reliable. 
515

516

517

518

519

520

521

522

523

524

525

526

527

528

529

530

531

532

533

534

535

536

537

538

539

540

541

542

543

544

545

546

547

548

549

550

551

552

553

554

Additionally, communities placed in the semi-arid region are established on the region longer than the TR populations, which may also have influenced the results (eg. perhaps longer living in contact with the environment favored greater medical knowledge on native flora to treat a larger set of diseases, which could contribute to a more significant number of equivalent pairs). Therefore, we propose that future studies on utilitarian equivalence include TR communities with longer histories in the region.

\section{Conclusions}

Here, both Utilitarian equivalence and Utilitarian redundancy have been taxonomically influenced, possibly due to the chemical similarities that taxonomically close plants tend to possess and due to cultural traits that modulate plant selection and the transmission of knowledge. However, the central element behind the taxonomic influence seems to be the therapeutic efficacy, that is, the success of the plant in curing a particular disease, which in turn is strongly related to the repertoire of chemical compounds of the species. In addition, the Utilitarian equivalence approach between local medical systems of dry forests and wetlands has shown that even among communities that are subject to characteristic climates and distinct native floras, there are similar adaptive responses. In this sense, the mechanisms of selection of medicinal plants involve certain behaviors and perceptions common to different peoples. Regarding the choice of plants for pharmacological studies, our findings indicate the feasibility of using a chemosystematic approach, that is, selection of plants phylogenetically close to the species with previously proven pharmacological activity.

\section{Acknowledgements}

We wish to thank the communities Igrejinha, Batinga, Assentamento Dom Helder Câmara and Assentamento Che Guevara, for the extraordinary receptivity which allowed the obtainment of the necessary data. We also thank Denis Linhares Corrêa for collaborating with the construction of the data bank used in the present study.

\section{References}

1. Moerman DE. The medicinal flora of native North America: an analysis. Journal of Ethnopharmacology. 1991. https://doi.org/10.1016/0378-8741(91)90141-Y

2. Brown KA, Flynn DFB, Abram NK, Ingram C, Johnson SE, Wright P. Assessing Natural Resource Use by Forest-Reliant Communities in Madagascar Using Functional Diversity and Functional Redundancy Metrics. Plos One. 2011. https://doi.org/10.1371/journal.pone.0024107

3. Saslis-Lagoudakis CH, Savolainen V, Williamson EM, Forest F, Wagstaff SJ, Baral SR. Phylogenies reveal predictive power of traditional medicine in bioprospecting. Proc. Natl. Acad. Sci. U.S.A. 2012. https://doi.org/10.1073/pnas.1202242109 
555

556

557

558

559

560

561

562

563

564

565

566

567

568

569

570

571

572

573

574

575

576

577

578

579

580

581

582

583

584

585

586

587

588

589

590

591

592

593

594

4. Ferreira Júnior, W.S., Campos, L.Z. de O., Pieroni, A., Albuquerque, Ulysses P., 2015. Biological and Cultural Bases of the Use of Medicinal and Food Plants, in: Albuquerque, Ulysses Paulino, Medeiros, P.M. de, Casas, A. (Eds.), Evolutionary Ethnobiology. pp. 175-184. https://doi.org/10.1007/978-3-319-02904-7

5. Albuquerque UP, Oliveira RF. Is the use-impact on native Caatinga species in Brazil reduced by the high species richness of medicinal plants? J. Ethnopharmacol. 2007.

https://doi.org/10.1016/j.jep.2007.05.025

6. Nascimento ALB, Ferreira-Júnior WS, Ramos MA, Medeiros PM, Soldati GT, Santoro FR, Albuquerque UP. Utilitarian Redundancy: Conceptualization and Potential Applications in Ethnobiological Research. In U. P, Albuquerque UP, Medeiros PM. Evolutionary Ethnobiology. Springer. New York, NY. 2015. p. 163-174.

7. Santoro, FR. Plantas medicinais, redundância utilitária e resiliência de sistemas médicos locais na caatinga. Dissertação (Mestrado em Ecologia) - Universidade Federal Rural de Pernambuco, Recife. 2014. http://www.tede2.ufrpe.br:8080/tede2/handle/tede2/5262 accessed on February 25, 2020 .

8. Phillips O, Gentry AH. The useful plants of Tambopata, Peru: I. Statistical hypotheses tests with a new quantitative technique. Econ. Bot. 1993;47: 15-32.

https://doi.org/10.1007/BF02862203

9. Gonçalves PHS, Albuquerque UP, Medeiros PM. The most commonly available woody plant species are the most useful for human populations: A meta-analysis. Ecol. Applications. 2016. https://doi.org/10.1002/eap.1364

10. Ankli A, Sticher O, Heinrich M. Yucatec Maya medicinal plants versus non medicinal plants: indigenous Characterization and seletion. Hum. Ecol. 1999. 27(4): 557-580. doi 03007839/99/1200-0557\$1 6.00/0. https://link.springer.com/article/10.1023/A:1018791927215

11. Saslis-Lagoudakis CH, Hawkins JA, Greenhill SJ, Pendry CA, Watson MF, TuladharDouglas W, Baral SR, Savolainen V. The evolution of t raditional knowledge: environment shapes medicinal plant use in Nepal. Proceedings of the Royal Societes. 2014; 281. Doi: 10.1098/rspb.2013.2768

12. Leonti MAL, Ramirez F, Ticher O, Heinrich M. Medicinal flora of the Popoluca, México: a botanical systematical perspective. Econ. Bot. 2003; 57: 218-230. https://doi.org/10.1663/00130001(2003)057[0218:MFOTPM]2.0.CO;2. 
596 13. Leonti M, Casu L, Sanna F, Bonsignore L. A comparison of medicinal plant use in Sardinia 597 and Sicily-De Materia Medic are visited. J. Ethnopharmacol. 2009.

598 https://doi.org/10.1016/j.jep.2008.10.027

599

600 14. Ferreira-Junior WS, Albuquerque UP. Theoretical review on the origin of medicinal practices 601 in humans: echoes from evolution. Ethnobiol. Conserv. 2018. 7(3). doi:10.15451/ec2018-02-

602 7.03-1-7 https://www.ethnobioconservation.com/index.php/ebc/article/view/126 accessed on 603 February 25, 2020.

604

605 15. Medeiros PM, Ladio AH, Albuquerque UP. Local criteria for Medicinal Plant Selection. In 606 U. P, Albuquerque, P. M, Medeiros, Casas, A. (Eds.). Evolutionary Ethnobiology. Springer. New 607 York, NY; 2015. p. 149-163.

608

609

16. Odum EP. Fundamental of Ecology. Philadelphia: W.B. Saunders .1971.

610 17. Begon M, Townsend CR, Harper JL. Ecology from Individuals to Ecosystems. Wiley. New 611 York, NY. 2006.

612

613 18. Hutchinson GE. Population studies-animal ecology and demography-concluding remarks.

614 Cold Spring Harbor Symposia on Quantitative Biology. 1957. 22(1): 415-427.

615 https://doi.org/10.1007/BF02464429

616

617 19. Fišer Ž, Altermatt Ž, Zakšek1 V, Knapič4 T, Fišer C. Morphologically Cryptic Amphipod 618 Species Are "Ecological Clones" at Regional but Not at Local Scale: A Case Study of Four 619 Niphargus Species. PLoS ONE. 2015. https://doi.org/10.1371/journal.pone.0134384

620

621 20. Garnatje T, Peñulas J, Vallès, J. Ethnobotany, phylogeny, and 'omics' for human health and 622 food security. Trends Plant Sci. 2017. https://doi.org/10.1016/j.tplants.2017.01.001

623

624 21. Hawkins J, Teixidor-Toneu TI. Defining 'ethnobotanical convergence'. Trends in Plant

625 Science. 2017. https://doi.org/10.1016/j.tplants.2017.06.002

626

627 22. IBAMA. 2006. Plano operativo de prevenção e combate aos incêndios florestais da Estação 628 Ecológica de Murici. Murici, IBAMA. 15p.

629 https://licenciamento.ibama.gov.br/phocadownload/prevfogo/planos_operativos/34-

630 estacao_ecologica_urucui_una-pi.pdf accessed on February 25, 2020.

631

632 23. Cavalcanti BC \& Barros RRA. Desejos de cidade - imaginários urbanos em assentamentos 633 rurais numa área de reservade mata atlântica brasileira. Horizontes Antropológicos. 2006; 25, 
634 217-235. Doi:10.1590/s0104-71832006000100011 Available online at:

635 http://www.scielo.br/pdf/ha/v12n25/a11v1225.pdf accessed on February 25, 2020.

636

637 24. SEPLAG/AL - Secretaria de estado do planejamento, gestão e patrimônio do estado de

638 Alagoas. Perfil Municipal, Ano 3, no 3 (2012). Maceió: Secretaria de Estado do

639 Planejamento, Gestão e Patrimônio. Available online at: http://www.dados.al.gov.br.

640 accessed on February 25, 2020.

641

642 25. Ribeiro EMS, Arroyo-Rodríguez V, Santos BA, Tabarelli M, Leal IR (2015) Chronic

643 anthropogenic disturbance drives the biological impoverishment of the Brazilian Caatinga

644 vegetation. J Appl Ecol 52:611-620

645

646 26. Alvares CA, Stape JL, Sentelhas PC, Gonçalves JLM, Sparovek, G. Köppen's climate

647 classification map for Brazil. Meteorol. Z. 2013. 22(6): 711-728. doi: 10.1127/0941-

648 2948/2013/0507.https://www.schweizerbart.de/papers/metz/detail/22/82078/Koppen_s_climate_

649 classification_map_for_Brazil?af=crossref accessed on February 25, 2020.

650

651

652

653 28. Albuquerque UP, Ramos MA, Lucena RFP, Alencar NL. Methods and techniques used to

654 collect ethnobiological data. In U. P, Albuquerque UP, Lucena RFP, Cunha LVFC. Methods and

655 techniques in ethnobiology and ethnoecology. Springer. New York, NY; 2014. p. 15-38.

656 https://doi.org/10.1007/978-1-4614-8636-7_2

657

658

29. Albuquerque UP, Lucena RFP, Lins-Neto EMF. Selection of Research Participants. In:

659 Albuquerque UP, Lucena RFP, Cunha LVFC, editors. Methods and Techniques in Ethnobiology

660 and Ethnoecology. Springer. New York, NY; 2014. p. 7-14.

661

662 30. The Angiosperm Phylogeny Group. An update of the Angiosperm Phylogeny Group

663 classification for the orders and families of flowering plants: APG IV. Botanical Journal.

664 2016;181(1): 01-20. Doi: https://doi.org/10.1111/boj.12385

665

666

667

31. Molander M, Saslis-Lagoudakis, CH, Jäger AK, Rønsted N. Cross-cultural comparison of

668 medicinal floras used against snakebites. J. Ethnopharmacol. 2011.

669 https://doi.org/10.1016/j.jep.2011.12.032

670

671 32. Bletter N. A quantitative synthesis of the medicinal ethnobotany of the Malinké of Mali and 672 tha Asháninka of Peru, with a new theorical framework. J. Ethnobiol. Ethnomed. 2006;3(36).

673 Doi: 10.1186/1746-4269-3-36. https://www.ncbi.nlm.nih.gov/pmc/articles/PMC2248176/ 
674

675 33. Albuquerque UP. A little bit of Africa in Brazil: ethnobiology experiences in the field of

676 Afro-Brazilian religions. J. Ethnobiol. Ethnomed. 2014. 10(12): 12-19. doi: 10.1186/1746-4269-

677 10-12. https://ethnobiomed.biomedcentral.com/track/pdf/10.1186/1746-4269-10-12

678

679 34. Albuquerque UP. The use of medicinal plants by the cultural descendants of African people 680 in Brazil. Acta Farm. Bonaerense. 2011. 20(2): 139-144.

681 https://catbull.com/alamut/Bibliothek/LAJOP_20_2_1_9_X1A9PM770Z.pdf accessed on

682 February 25, 2020.

683

684 35. Rønsted N, Symonds MRE, Birkholm T, Christensen SB, Meerow AW, Molander M,

685 Mølgaard P, Petersen G, Rasmussen N, Staden JV, Stafford GI, Jäger AK. Can phylogeny

686 predict chemical diversity and potential medicinal activity of plants. A case study of

687 amaryllidaceae. Evol. Biol. 2012. doi: https://doi.org/10.1186/1471-2148-12-182

688

689 36. Medeiros PM, Albuquerque UP. Use Patterns of Medicinal Plants by Local Populations. In

690 U. P, Albuquerque, P. M, Medeiros, A, Casas, (Eds.). Evolutionary Ethnobiology. Springer. New

691 York, NY; 2015. p. 163-174.

692

693 37. Casagrande, DG. Human taste and cognition in Tzeltal Maya medicinal plant use. J. Ecol.

694 Anthropol. 2000. http://dx.doi.org/10.5038/2162-4593.4.1.3

695

696 38. Evert RF, and Eichhorn SE. Raven Biology of Plants. 8th Edition, W. H. Freeman,

697 Macmillan, 2013.

698

699 39. Marshall, MN. Sampling for Qualitative Research. Family Practice. 1996.

700 http://dx.doi.org/10.1093/fampra/13.6.522

701

702 40. Guest G, Namey E, McKenna K. how many focus groups are enough? Building an evidence 703 base for nonprobability sample sizes. Field Methods. 2017:3-22.

704

705 


\section{Table 1 (on next page)}

Distribution of local experts interviewed by community and by sex. 
1 Table 1. Distribution of local experts interviewed by community and by gender.

2

\begin{tabular}{llccc}
\hline Ecosystem & Community & Men & Women & Total \\
\hline Atlantic Forest & Ass. D. Helder Câm & 15 & 11 & 26 \\
& Ass. Che Guevara & 11 & 2 & 13 \\
& Igrejinha & 26 & 34 & 59 \\
\cline { 2 - 5 } Caatinga & Batinga & 13 & 16 & 29 \\
& & 65 & 63 & 127
\end{tabular}

3 


\section{Table 2 (on next page)}

Taxonomic affiliation, therapeutic indications and popular names of the 64 species obtained from the local experts of each phytophysiognomic region (Seasonally Dry Tropical Forest and Tropical Rainforest).

SDTF indicates that the species in question was obtained in the Seasonally Dry Tropical Forest, while TR indicates that the species was collected from the Tropical Rainforest. 
Table 2. Taxonomic affiliation, therapeutic indications and popular names of the 64 species obtained from the local experts of each 2 phytophysiognomic region (Seasonally Dry Tropical Forest and Tropical Rainforest).

\begin{tabular}{|c|c|c|c|c|c|c|c|c|}
\hline Family & Genus & $\begin{array}{l}\text { Medicinal } \\
\text { plants }\end{array}$ & $\begin{array}{l}\text { Common } \\
\text { name }\end{array}$ & Origin & $\begin{array}{l}\text { Region } \\
*\end{array}$ & $\begin{array}{l}\text { Part of the } \\
\text { plant used }\end{array}$ & $\begin{array}{l}\text { Therapeutic } \\
\text { indications }\end{array}$ & $\begin{array}{l}\text { Herbarium } \\
\text { voucher }\end{array}$ \\
\hline \multirow[t]{2}{*}{ Adoxaceae } & Sambucus & $\begin{array}{l}\text { Sambucus } \\
\text { nigra L. }\end{array}$ & $\begin{array}{l}\text { Sabugueir } \\
\text { a }\end{array}$ & Exotic & SDTF & Flower & $\begin{array}{l}\text { Flu \& colds } \\
\& \text { Cough. }\end{array}$ & HST22162 \\
\hline & & & & & $\mathrm{TR}$ & $\begin{array}{l}\text { Flower \& } \\
\text { Leaves }\end{array}$ & Colds \& flu. & $\begin{array}{l}\text { Sterile } \\
\text { material }\end{array}$ \\
\hline \multirow[t]{2}{*}{$\begin{array}{l}\text { Amaranthacea } \\
\text { e }\end{array}$} & Dysphania & $\begin{array}{l}\text { Dysphania } \\
\text { ambrosioides } \\
\text { (L.) Mosyakin } \\
\text { \& Clemants }\end{array}$ & Mastruz & Exotic & SDTF & $\begin{array}{l}\text { Entire plant } \\
\text { or Roots }\end{array}$ & $\begin{array}{l}\text { Expectorant, } \\
\text { Injury, Bone } \\
\text { fracture, Flu } \\
\& \text { colds, } \\
\text { Cough, } \\
\text { Worms \& } \\
\text { Stomach } \\
\text { problems. }\end{array}$ & IPA91613 \\
\hline & & & & & TR & Leaves & $\begin{array}{l}\text { Expectorant, } \\
\text { Flu \& colds, } \\
\text { Cough \& } \\
\text { Worms. }\end{array}$ & IPA91714 \\
\hline \multirow[t]{3}{*}{ Anacardiaceae } & Anacardium & $\begin{array}{l}\text { Anacardium } \\
\text { occidentale L. }\end{array}$ & $\begin{array}{l}\text { Cajueiro } \\
\text { roxo }\end{array}$ & Native & SDTF & $\begin{array}{l}\text { Bark \& } \\
\text { Leaves }\end{array}$ & $\begin{array}{l}\text { Toothache, } \\
\text { Injury, } \\
\text { Stomach } \\
\text { problems \& } \\
\text { Inflammatio } \\
\text { n in general. }\end{array}$ & $\begin{array}{l}\text { Sterile } \\
\text { material }\end{array}$ \\
\hline & & & & & TR & $\begin{array}{l}\text { Bark \& } \\
\text { fruit }\end{array}$ & $\begin{array}{l}\text { Toothache, } \\
\text { Injury, } \\
\text { Gynecologic } \\
\text { al \& } \\
\text { Problem. }\end{array}$ & $\begin{array}{l}\text { Sterile } \\
\text { material }\end{array}$ \\
\hline & Myracrodruon & Myracrodruon & Aroeira & Native & SDTF & Bark, stem, & Pain in & Sterile \\
\hline
\end{tabular}




\begin{tabular}{|c|c|c|c|c|c|c|c|c|}
\hline Family & Genus & $\begin{array}{l}\text { Medicinal } \\
\text { plants }\end{array}$ & $\begin{array}{l}\text { Common } \\
\text { name }\end{array}$ & Origin & $\begin{array}{l}\text { Region } \\
*\end{array}$ & $\begin{array}{l}\text { Part of the } \\
\text { plant used }\end{array}$ & $\begin{array}{l}\text { Therapeutic } \\
\text { indications }\end{array}$ & $\begin{array}{l}\text { Herbarium } \\
\text { voucher }\end{array}$ \\
\hline & & $\begin{array}{l}\text { urundeuva } \\
\text { Allemão }\end{array}$ & & & & $\begin{array}{l}\text { flower \& } \\
\text { Leaves }\end{array}$ & $\begin{array}{l}\text { general, } \\
\text { Acariasis \& } \\
\text { other } \\
\text { infestations, } \\
\text { Injury, } \\
\text { Stomach } \\
\text { problems, } \\
\text { Indigestion, } \\
\text { Inflammatio } \\
\text { n in general } \\
\text { \& Cough. }\end{array}$ & material \\
\hline & Schinopsis & $\begin{array}{l}\text { Schinopsis } \\
\text { brasiliensis } \\
\text { Engl. }\end{array}$ & Baraúna & Native & SDTF & $\begin{array}{l}\text { Bark, stem, } \\
\text { Leaves, sap } \\
\& \text { resin }\end{array}$ & $\begin{array}{l}\text { Headache, } \\
\text { Flu \& colds. }\end{array}$ & $\begin{array}{l}\text { Sterile } \\
\text { material }\end{array}$ \\
\hline & Schinus & $\begin{array}{l}\text { Schinus } \\
\text { terebinthifolia } \\
\text { var. acutifolia } \\
\text { Engl. }\end{array}$ & Aroeira & Native & TR & $\begin{array}{l}\text { Bark, } \\
\text { Leaves }\end{array}$ & $\begin{array}{l}\text { Injury, } \\
\text { General } \\
\text { inflammation } \\
\& \\
\text { Gynecologic } \\
\text { al problem. }\end{array}$ & $\begin{array}{l}\text { Sterile } \\
\text { material }\end{array}$ \\
\hline & Spondias & $\begin{array}{l}\text { Spondias } \\
\text { tuberosa L. }\end{array}$ & $\begin{array}{l}\text { Umbuzeir } \\
\text { o }\end{array}$ & Native & SDTF & $\begin{array}{l}\text { Bark \& } \\
\text { Leaves }\end{array}$ & $\begin{array}{l}\text { Calming, } \\
\text { Diarrhea \& } \\
\text { Insomnia. }\end{array}$ & $\begin{array}{l}\text { Sterile } \\
\text { material }\end{array}$ \\
\hline & Tapirira & $\begin{array}{l}\text { Tapirira } \\
\text { guianensis } \\
\text { Aubl. }\end{array}$ & Cupiuba & Native & TR & $\begin{array}{l}\text { Sap \& } \\
\text { Resin }\end{array}$ & Injury. & $\begin{array}{l}\text { Sterile } \\
\text { material }\end{array}$ \\
\hline Annonaceae & Xylopia & $\begin{array}{l}\text { Xylopia } \\
\text { frutescens aubl. }\end{array}$ & $\begin{array}{l}\text { Imbira } \\
\text { Vermelha }\end{array}$ & Native & TR & Seeds. & $\begin{array}{l}\text { Pain in } \\
\text { general. }\end{array}$ & $\begin{array}{l}\text { Sterile } \\
\text { material }\end{array}$ \\
\hline Arecaceae & Syagrus & $\begin{array}{l}\text { Syagrus } \\
\text { coronata } \\
\text { (Mart.) Becc. }\end{array}$ & $\begin{array}{l}\text { Coco } \\
\text { Ouricuri }\end{array}$ & Native & SDTF & Roots & $\begin{array}{l}\text { Airways } \\
\text { inflammation } \\
\& \text { Spine }\end{array}$ & $\begin{array}{l}\text { Sterile } \\
\text { material }\end{array}$ \\
\hline
\end{tabular}




\begin{tabular}{|c|c|c|c|c|c|c|c|c|}
\hline Family & Genus & $\begin{array}{l}\text { Medicinal } \\
\text { plants }\end{array}$ & $\begin{array}{l}\text { Common } \\
\text { name }\end{array}$ & Origin & $\underset{*}{\text { Region }}$ & $\begin{array}{l}\text { Part of the } \\
\text { plant used }\end{array}$ & $\begin{array}{l}\text { Therapeutic } \\
\text { indications }\end{array}$ & $\begin{array}{l}\text { Herbarium } \\
\text { voucher }\end{array}$ \\
\hline & & & & & & & problems. & \\
\hline Asphodelaceae & Aloe & $\begin{array}{l}\text { Aloe vera (L.) } \\
\text { Burm. f. }\end{array}$ & Babosa & Exotic & SDTF & $\begin{array}{l}\text { Bark, } \\
\text { Leaves \& } \\
\text { roots }\end{array}$ & $\begin{array}{l}\text { Expectorant, } \\
\text { injury, } \\
\text { stomach } \\
\text { problems, flu } \\
\text { \& colds, } \\
\text { cough \& } \\
\text { worms. }\end{array}$ & $\begin{array}{l}\text { Sterile } \\
\text { material }\end{array}$ \\
\hline \multirow[t]{2}{*}{ Asteraceae } & $\begin{array}{l}\text { Acanthospermu } \\
m\end{array}$ & $\begin{array}{l}\text { Acanthospermu } \\
\text { m hispidum } \\
\text { DC. }\end{array}$ & Federação & Native & SDTF & $\begin{array}{l}\text { Leaves \& } \\
\text { roots }\end{array}$ & $\begin{array}{l}\text { Expectorant, } \\
\text { cough, flu \& } \\
\text { colds. }\end{array}$ & IPA91626 \\
\hline & & & & & $\mathrm{TR}$ & $\begin{array}{l}\text { Flower \& } \\
\text { roots }\end{array}$ & Cough. & $\begin{array}{l}\text { Sterile } \\
\text { material }\end{array}$ \\
\hline \multirow[t]{2}{*}{ Bignoniaceae } & Handroantus & $\begin{array}{l}\text { Handroantus } \\
\text { impetiginosus } \\
\text { (Mart.ex DC.) } \\
\text { Mattos }\end{array}$ & $\begin{array}{l}\text { Pau } \\
\text { D’arco } \\
\text { Roxo }\end{array}$ & Native & SDTF & Bark & $\begin{array}{l}\text { Stomach } \\
\text { problems. }\end{array}$ & $\begin{array}{l}\text { Sterile } \\
\text { material }\end{array}$ \\
\hline & & & & & $\mathrm{TR}$ & Bark & Wounds. & $\begin{array}{l}\text { Sterile } \\
\text { material }\end{array}$ \\
\hline Bromeliaceae & Neoglaziovia & $\begin{array}{l}\text { Neoglaziovia } \\
\text { variegata } \\
\text { (Arruda) Mez }\end{array}$ & Caruá & Native & SDTF & Roots & $\begin{array}{l}\text { Spine } \\
\text { problems. }\end{array}$ & IPA91701 \\
\hline \multirow[t]{2}{*}{ Burseraceae } & Commiphora & $\begin{array}{l}\text { Commiphora } \\
\text { leptophloeos } \\
\text { (Mart.) } \\
\text { J.B.Gillett }\end{array}$ & $\begin{array}{l}\text { Imburana } \\
\text { de cambão }\end{array}$ & Native & SDTF & $\begin{array}{l}\text { Bark \& } \\
\text { Leaves }\end{array}$ & $\begin{array}{l}\text { Diarrhea, } \\
\text { Injury, } \\
\text { Hypertension } \\
\text { \& Cough. }\end{array}$ & IPA91663 \\
\hline & Protium & $\begin{array}{l}\text { Protium } \\
\text { heptaphyllum } \\
\text { (Aubl.) }\end{array}$ & Amescla & Native & $\mathrm{TR}$ & $\begin{array}{l}\text { Sap/resin } \\
\& \text { Seeds }\end{array}$ & $\begin{array}{l}\text { Toothache, } \\
\text { Stomach } \\
\text { problems. }\end{array}$ & $\begin{array}{l}\text { Sterile } \\
\text { material }\end{array}$ \\
\hline capparaceae & Tarenaya & $\begin{array}{l}\text { Tarenaya } \\
\text { spinosa Jacq.) }\end{array}$ & Mussambe & Native & TR & $\begin{array}{l}\text { Flower \& } \\
\text { Roots }\end{array}$ & Flu \& colds. & $\begin{array}{l}\text { Sterile } \\
\text { material }\end{array}$ \\
\hline
\end{tabular}




\begin{tabular}{|c|c|c|c|c|c|c|c|c|}
\hline Family & Genus & $\begin{array}{l}\text { Medicinal } \\
\text { plants }\end{array}$ & $\begin{array}{l}\text { Common } \\
\text { name }\end{array}$ & Origin & $\begin{array}{l}\text { Region } \\
*\end{array}$ & $\begin{array}{l}\text { Part of the } \\
\text { plant used }\end{array}$ & $\begin{array}{l}\text { Therapeutic } \\
\text { indications }\end{array}$ & $\begin{array}{l}\text { Herbarium } \\
\text { voucher }\end{array}$ \\
\hline & & Raf. & & & & & & \\
\hline \multirow[t]{2}{*}{$\begin{array}{l}\text { Euphorbiacea } \\
\text { e }\end{array}$} & Astraea & $\begin{array}{l}\text { Astraea lobata } \\
\text { (L.) Klotzsch }\end{array}$ & $\begin{array}{l}\text { Alfavaca } \\
\text { de cobra }\end{array}$ & Native & TR & Roots & $\begin{array}{l}\text { Stinging of } \\
\text { venomous } \\
\text { animals. }\end{array}$ & $\begin{array}{l}\text { Sterile } \\
\text { material }\end{array}$ \\
\hline & Jatropha & $\begin{array}{l}\text { Jatropha } \\
\text { gossypiifolia L. }\end{array}$ & $\begin{array}{l}\text { Pinhão } \\
\text { Roxo }\end{array}$ & Native & SDTF & $\begin{array}{l}\text { Leaves, } \\
\text { shoot, sap } \\
\& \text { resin }\end{array}$ & $\begin{array}{l}\text { Stinging of } \\
\text { venomous } \\
\text { animals. }\end{array}$ & IPA91702 \\
\hline \multirow[t]{5}{*}{ Fabaceae } & Amburana & $\begin{array}{l}\text { Amburana } \\
\text { Cearensis } \\
\text { (Allemão) } \\
\text { A.C.Sm. }\end{array}$ & $\begin{array}{l}\text { Imburana } \\
\text { de cheiro }\end{array}$ & Native & SDTF & $\begin{array}{l}\text { Bark, } \\
\text { Leaves \& } \\
\text { Seeds. }\end{array}$ & $\begin{array}{l}\text { Diarrhea, } \\
\text { Headache, } \\
\text { Flu \& colds, } \\
\text { Indigestion } \\
\text { \& Cough. }\end{array}$ & $\begin{array}{l}\text { Sterile } \\
\text { material }\end{array}$ \\
\hline & Anadenanthera & $\begin{array}{l}\text { Anadenanthera } \\
\text { colubrina var. } \\
\text { cebil (Griseb.) } \\
\text { Altschul }\end{array}$ & Angico & Native & SDTF & Bark & $\begin{array}{l}\text { Injury, Flu \& } \\
\text { colds \& } \\
\text { Inflammatio } \\
\text { n in general. }\end{array}$ & IPA91649 \\
\hline & Bauhinia & $\begin{array}{l}\text { Bauhinia } \\
\text { acuruana } \\
\text { Moric. }\end{array}$ & Mororó & Native & SDTF & $\begin{array}{l}\text { Bark, } \\
\text { Leaves \& } \\
\text { Roots }\end{array}$ & $\begin{array}{l}\text { Diabetes, Flu } \\
\text { \& colds, } \\
\text { Inflammatio } \\
\mathrm{n} \text { in general } \\
\text { \& Cough. }\end{array}$ & IPA91660 \\
\hline & Copaifera & Copaifera $s p$. & $\begin{array}{l}\text { Pau } \\
\text { D’óleo }\end{array}$ & Native & $\mathrm{TR}$ & $\begin{array}{l}\text { Sap \& } \\
\text { Resin }\end{array}$ & $\begin{array}{l}\text { Pain in } \\
\text { general \& } \\
\text { stroke. }\end{array}$ & $\begin{array}{l}\text { Sterile } \\
\text { material }\end{array}$ \\
\hline & Hymenaea & $\begin{array}{l}\text { Hymenaea } \\
\text { courbaril L. }\end{array}$ & Jatobá & Native & SDTF & $\begin{array}{l}\text { Bark, fruit } \\
\& \text { roots }\end{array}$ & $\begin{array}{l}\text { Anemia, } \\
\text { Expectorant, } \\
\text { Injury, } \\
\text { Stomach } \\
\text { problems, } \\
\text { Flu \& colds, } \\
\text { Airway }\end{array}$ & IPA91630 \\
\hline
\end{tabular}




\begin{tabular}{|c|c|c|c|c|c|c|c|c|}
\hline \multirow{3}{*}{\multicolumn{2}{|c|}{ Family }} & $\begin{array}{l}\text { Medicinal } \\
\text { plants }\end{array}$ & $\begin{array}{l}\text { Common } \\
\text { name }\end{array}$ & Origin & $\begin{array}{l}\text { Region } \\
*\end{array}$ & $\begin{array}{l}\text { Part of the } \\
\text { plant used }\end{array}$ & $\begin{array}{l}\text { Therapeutic } \\
\text { indications }\end{array}$ & $\begin{array}{l}\text { Herbarium } \\
\text { voucher }\end{array}$ \\
\hline & & & & & & & \multicolumn{2}{|l|}{$\begin{array}{l}\text { inflammation } \\
\text { Inflammatio } \\
\mathrm{n} \text { in general } \\
\text { \& Cough. }\end{array}$} \\
\hline & & & & & $\mathrm{TR}$ & $\begin{array}{l}\text { Bark \& } \\
\text { fruit }\end{array}$ & $\begin{array}{l}\text { Injury \& } \\
\text { Airway } \\
\text { inflammation }\end{array}$ & $\begin{array}{l}\text { Sterile } \\
\text { material }\end{array}$ \\
\hline & Libidibia & $\begin{array}{l}\text { Libidibia ferrea } \\
\text { (Mart. ex Tul.) } \\
\text { L.P.Queiroz }\end{array}$ & Jucá & Native & SDTF & $\begin{array}{l}\text { Bark \& } \\
\text { fruit }\end{array}$ & Toothache. & IPA91696 \\
\hline & Mimosa & $\begin{array}{l}\text { Mimosa } \\
\text { tenuiflora } \\
\text { (Willd.) Poir. }\end{array}$ & $\begin{array}{l}\text { Jurema } \\
\text { Preta }\end{array}$ & Native & SDTF & Bark & Injury. & $\begin{array}{l}\text { Sterile } \\
\text { material }\end{array}$ \\
\hline & Periandra & $\begin{array}{l}\text { Periandra } \\
\text { mediterranea } \\
\text { (Vell.) Taub. }\end{array}$ & Alcançu & Native & SDTF & $\begin{array}{l}\text { Bark, } \\
\text { Leaves \& } \\
\text { Roots }\end{array}$ & $\begin{array}{l}\text { Expectorant, } \\
\text { Flu \& colds, } \\
\text { Airways } \\
\text { inflammation } \\
\text { \& Cough. }\end{array}$ & IPA91648 \\
\hline & Pityrocarpa & $\begin{array}{l}\text { Pityrocarpa } \\
\text { moniliformis } \\
\text { (Benth.) } \\
\text { Luckow \& } \\
\text { R.W.Jobson }\end{array}$ & Canzenzo & Native & SDTF & Bark & Diarrhea. & IPA91651 \\
\hline & Poincianella & $\begin{array}{l}\text { Poincianella } \\
\text { microphylla } \\
\text { (Mart. ex } \\
\text { G.Don) } \\
\text { L.P.Queiroz }\end{array}$ & $\begin{array}{l}\text { Catingueir } \\
\text { a rasteira }\end{array}$ & Native & SDTF & $\begin{array}{l}\text { Bark, } \\
\text { flower \& } \\
\text { Roots }\end{array}$ & $\begin{array}{l}\text { Inflammatio } \\
\mathrm{n} \text { in general } \\
\& \text { Cough. }\end{array}$ & IPA91653 \\
\hline & Prosopis & Prosopis & Algaroba & Exotic & SDTF & Bark & Inflammatio & Sterile \\
\hline
\end{tabular}




\begin{tabular}{|c|c|c|c|c|c|c|c|c|}
\hline Family & Genus & $\begin{array}{l}\text { Medicinal } \\
\text { plants }\end{array}$ & $\begin{array}{l}\text { Common } \\
\text { name }\end{array}$ & Origin & $\underset{*}{\text { Region }}$ & $\begin{array}{l}\text { Part of the } \\
\text { plant used }\end{array}$ & $\begin{array}{l}\text { Therapeutic } \\
\text { indications }\end{array}$ & $\begin{array}{l}\text { Herbarium } \\
\text { voucher }\end{array}$ \\
\hline & & juliflora (Sw.) & & & & & $\mathrm{n}$ in general. & material \\
\hline & Senegalia & $\begin{array}{l}\text { Senegalia } \\
\text { bahiensis } \\
\text { (Benth.) Seigler } \\
\text { \& Ebinger }\end{array}$ & Carcará & Native & SDTF & $\begin{array}{l}\text { Bark \& } \\
\text { Roots }\end{array}$ & $\begin{array}{l}\text { Spine } \\
\text { problems \& } \\
\text { Kidney } \\
\text { problems. }\end{array}$ & IPA91697 \\
\hline & Senna & $\begin{array}{l}\text { Senna } \\
\text { occidentalis } \\
\text { (L.) Link }\end{array}$ & $\begin{array}{l}\text { Mangeriob } \\
\text { a }\end{array}$ & Native & $\mathrm{TR}$ & $\begin{array}{l}\text { Flower \& } \\
\text { Seeds }\end{array}$ & $\begin{array}{l}\text { Headache, } \\
\text { Airways } \\
\text { Inflammatio } \\
\text { n. }\end{array}$ & IPA91706 \\
\hline & Senna & $\begin{array}{l}\text { Senna } \\
\text { spectabilis var. } \\
\text { excelsa } \\
\text { (Schrad.) } \\
\text { H.S.Irwin \& } \\
\text { Barneby }\end{array}$ & $\begin{array}{l}\text { Canafístul } \\
\text { a }\end{array}$ & Native & SDTF & Bark & Diarrhea. & HST22166 \\
\hline Hypericaceae & Vismia & $\begin{array}{l}\text { Vismia } \\
\text { guianensis } \\
\text { (Aubl.) Choisy }\end{array}$ & Lacre & Native & $\mathrm{TR}$ & $\begin{array}{l}\text { Bark, } \\
\text { Leaves \& } \\
\text { Roots }\end{array}$ & $\begin{array}{l}\text { Arterial } \\
\text { hypertension } \\
\text { \& Renal } \\
\text { problems. }\end{array}$ & IPA91717 \\
\hline \multirow[t]{3}{*}{ Lamiaceae } & Lippia & $\begin{array}{l}\text { Lippia } \\
\text { origanoides } \\
\text { Kunth }\end{array}$ & $\begin{array}{l}\text { Alecrim } \\
\text { do Mato }\end{array}$ & Native & SDTF & Leaves & $\begin{array}{l}\text { Toothache \& } \\
\text { Headache. }\end{array}$ & IPA91612 \\
\hline & Mentha & $\begin{array}{l}\text { Mentha } \\
\text { piperita L. }\end{array}$ & $\begin{array}{l}\text { Hortelã da } \\
\text { folha } \\
\text { pequena }\end{array}$ & Exotic & SDTF & $\begin{array}{l}\text { Leaves \& } \\
\text { roots }\end{array}$ & $\begin{array}{l}\text { Expectorant, } \\
\text { Flu \& colds, } \\
\text { Airways } \\
\text { Inflammatio } \\
\text { n \& Cough. }\end{array}$ & $\begin{array}{l}\text { Sterile } \\
\text { material }\end{array}$ \\
\hline & Ocimum & $\begin{array}{l}\text { Ocimum } \\
\text { gratissimum L. }\end{array}$ & Alfavaca & Exotic & $\mathrm{TR}$ & Leaves & $\begin{array}{l}\text { Stomach } \\
\text { problems \& } \\
\text { conjunctiviti } \\
\text { s. }\end{array}$ & $\begin{array}{l}\text { Sterile } \\
\text { material }\end{array}$ \\
\hline
\end{tabular}




\begin{tabular}{|c|c|c|c|c|c|c|c|c|}
\hline Family & Genus & $\begin{array}{l}\text { Medicinal } \\
\text { plants }\end{array}$ & $\begin{array}{l}\text { Common } \\
\text { name }\end{array}$ & Origin & $\underset{*}{\text { Region }}$ & $\begin{array}{l}\text { Part of the } \\
\text { plant used }\end{array}$ & $\begin{array}{l}\text { Therapeutic } \\
\text { indications }\end{array}$ & $\begin{array}{l}\text { Herbarium } \\
\text { voucher }\end{array}$ \\
\hline & Plectranthus & $\begin{array}{l}\text { Plectranthus } \\
\text { amboinicus } \\
\text { (Lour.) Spreng. }\end{array}$ & $\begin{array}{l}\text { Hortelã da } \\
\text { folha } \\
\text { grande }\end{array}$ & Exotic & SDTF & Leaves & $\begin{array}{l}\text { Flu \& colds } \\
\& \text { Cough. }\end{array}$ & $\begin{array}{l}\text { Sterile } \\
\text { material }\end{array}$ \\
\hline & Rosmarinus & $\begin{array}{l}\text { Rosmarinus } \\
\text { officinalis L. }\end{array}$ & Alecrim & Exotic & SDTF & Leaves & $\begin{array}{l}\text { Headache, } \\
\text { Flu \& colds. }\end{array}$ & $\begin{array}{l}\text { Sterile } \\
\text { material }\end{array}$ \\
\hline Lauraceae & Persea & $\begin{array}{l}\text { Persea } \\
\text { americana } \\
\text { Mill. }\end{array}$ & Abacate & Exotic & SDTF & Leaves & $\begin{array}{l}\text { Renal } \\
\text { problems. }\end{array}$ & HST22158 \\
\hline Malvaceae & Guazuma & $\begin{array}{l}\text { Guazuma } \\
\text { ulmifolia Lam. }\end{array}$ & Mutamba & Native & $\mathrm{TR}$ & Bark & $\begin{array}{l}\text { Bone } \\
\text { fracture \& } \\
\text { Cough. }\end{array}$ & IPA91718 \\
\hline Maranthaceae & Maranta & Maranta sp. & Uruba & Native & $\mathrm{TR}$ & Roots & $\begin{array}{l}\text { Stinging of } \\
\text { venomous } \\
\text { animals. }\end{array}$ & $\begin{array}{l}\text { Sterile } \\
\text { material }\end{array}$ \\
\hline Moraceae & Sorocea & Sorocea sp. & Pau Teiu & Native & SDTF & $\begin{array}{l}\text { Bark, sap } \\
\& \text { resin }\end{array}$ & $\begin{array}{l}\text { Stinging of } \\
\text { venomous } \\
\text { animals. }\end{array}$ & $\begin{array}{l}\text { Sterile } \\
\text { material }\end{array}$ \\
\hline \multirow[t]{5}{*}{ Myrtaceae } & Plinia & $\begin{array}{l}\text { Plinia } \\
\text { cauliflora } \\
\text { (Mart.) Kausel }\end{array}$ & Jabuticaba & Native & SDTF & Bark & Diarrhea. & $\begin{array}{l}\text { Sterile } \\
\text { material }\end{array}$ \\
\hline & Psidium & $\begin{array}{l}\text { Psidium } \\
\text { guajava } \mathrm{L} .\end{array}$ & Goiaba & Exotic & SDTF & $\begin{array}{l}\text { Bark \& } \\
\text { Leaves }\end{array}$ & Diarrhea. & $\begin{array}{l}\text { Sterile } \\
\text { material }\end{array}$ \\
\hline & Psidium & $\begin{array}{l}\text { Psidium } \\
\text { guineense Sw. }\end{array}$ & Araçá & Native & TR & Leaves & Diarrhea. & IPA91708 \\
\hline & Psidium & Psidium sp. & Araçá & Native & SDTF & Bark & Diarrhea. & $\begin{array}{l}\text { Sterile } \\
\text { material }\end{array}$ \\
\hline & Syzygium & $\begin{array}{l}\text { Syzygium } \\
\text { cumini (L.) } \\
\text { Skeels }\end{array}$ & $\begin{array}{l}\text { Azeitona } \\
\text { Roxa }\end{array}$ & Exotic & $\mathrm{TR}$ & NA & Diabetes. & $\begin{array}{l}\text { Sterile } \\
\text { material }\end{array}$ \\
\hline Olacaceae & Ximenia & $\begin{array}{l}\text { Ximenia } \\
\text { americana linn }\end{array}$ & Ameixa & Native & SDTF & $\begin{array}{l}\text { Bark \& } \\
\text { Leaves }\end{array}$ & $\begin{array}{l}\text { Injury, } \\
\text { Throat }\end{array}$ & $\begin{array}{l}\text { Sterile } \\
\text { material }\end{array}$ \\
\hline
\end{tabular}




\begin{tabular}{|c|c|c|c|c|c|c|c|c|}
\hline Family & Genus & $\begin{array}{l}\text { Medicinal } \\
\text { plants }\end{array}$ & $\begin{array}{l}\text { Common } \\
\text { name }\end{array}$ & Origin & $\begin{array}{l}\text { Region } \\
*\end{array}$ & $\begin{array}{l}\text { Part of the } \\
\text { plant used }\end{array}$ & $\begin{array}{l}\text { Therapeutic } \\
\text { indications }\end{array}$ & $\begin{array}{l}\text { Herbarium } \\
\text { voucher }\end{array}$ \\
\hline & & & & & & & $\begin{array}{l}\text { problems, } \\
\text { Stomach } \\
\text { problems, } \\
\text { Inflammatio } \\
\text { n in general } \\
\& \\
\text { Gynecologic } \\
\text { al problem. }\end{array}$ & \\
\hline \multirow[t]{3}{*}{ Passifloraceae } & Passiflora & $\begin{array}{l}\text { Passiflora } \\
\text { cincinnata } \\
\text { Mast. }\end{array}$ & $\begin{array}{l}\text { Maracujá } \\
\text { do Mato }\end{array}$ & Native & SDTF & $\begin{array}{l}\text { Leaves, } \\
\text { fruit, roots } \\
\& \text { Seeds. }\end{array}$ & $\begin{array}{l}\text { Calming, Flu } \\
\& \text { colds, } \\
\text { Inflammatio } \\
\mathrm{n} \text { in general } \\
\text { \& Cough. }\end{array}$ & IPA91635 \\
\hline & Passiflora & $\begin{array}{l}\text { Passiflora } \\
\text { edulis Sims }\end{array}$ & Maracujá & Native & SDTF & Leaves & Indigestion. & $\begin{array}{l}\text { Sterile } \\
\text { material }\end{array}$ \\
\hline & Passiflora & $\begin{array}{l}\text { Passiflora } \\
\text { foetida } \mathrm{L} .\end{array}$ & $\begin{array}{l}\text { Maracujá } \\
\text { de Estralo }\end{array}$ & Native & SDTF & Leaves & $\begin{array}{l}\text { Flu \& colds } \\
\& \\
\text { Conjunctiviti } \\
\text { s. }\end{array}$ & IPA91677 \\
\hline \multirow[t]{2}{*}{$\begin{array}{l}\text { Phyllanthacea } \\
\text { e }\end{array}$} & Phyllanthus & $\begin{array}{l}\text { Phyllanthus } \\
\text { urinaria L. }\end{array}$ & $\begin{array}{l}\text { Quebra } \\
\text { Pedra }\end{array}$ & Native & SDTF & $\begin{array}{l}\text { Entire plant } \\
\text { \& Roots }\end{array}$ & $\begin{array}{l}\text { Renal } \\
\text { problems. }\end{array}$ & $\begin{array}{l}\text { Sterile } \\
\text { material }\end{array}$ \\
\hline & & & & & TR & $\begin{array}{l}\text { Entire plant } \\
\text { or Roots }\end{array}$ & $\begin{array}{l}\text { Renal } \\
\text { problems. }\end{array}$ & $\begin{array}{l}\text { Sterile } \\
\text { material }\end{array}$ \\
\hline $\begin{array}{l}\text { Plumbaginace } \\
\text { ae }\end{array}$ & Plumbago & $\begin{array}{l}\text { Plumbago } \\
\text { scandens L. }\end{array}$ & Louco & Native & SDTF & $\begin{array}{l}\text { Stem, } \\
\text { Leaves \& } \\
\text { Roots }\end{array}$ & Toothache. & HST22163 \\
\hline Poaceae & Cymbopogon & $\begin{array}{l}\text { Cymbopogon } \\
\text { citratus (DC) } \\
\text { Stapf. }\end{array}$ & $\begin{array}{l}\text { Capim } \\
\text { Santo }\end{array}$ & Exotic & SDTF & Leaves & $\begin{array}{l}\text { Calming, } \\
\text { Diarrhea, Flu } \\
\text { \& colds, } \\
\text { Hypertension } \\
\& \text { S }\end{array}$ & $\begin{array}{l}\text { Sterile } \\
\text { material }\end{array}$ \\
\hline
\end{tabular}




\begin{tabular}{|c|c|c|c|c|c|c|c|c|}
\hline Family & Genus & $\begin{array}{l}\text { Medicinal } \\
\text { plants }\end{array}$ & $\begin{array}{l}\text { Common } \\
\text { name }\end{array}$ & Origin & $\underset{*}{\text { Region }}$ & $\begin{array}{l}\text { Part of the } \\
\text { plant used }\end{array}$ & $\begin{array}{l}\text { Therapeutic } \\
\text { indications }\end{array}$ & $\begin{array}{l}\text { Herbarium } \\
\text { voucher }\end{array}$ \\
\hline & & & & & \multicolumn{4}{|c|}{ Indigestion. } \\
\hline & & & & & $\mathrm{TR}$ & Leaves & Diarrhea. & $\begin{array}{l}\text { Sterile } \\
\text { material }\end{array}$ \\
\hline Punicaceae & Punica & $\begin{array}{l}\text { Punica } \\
\text { granatum L. }\end{array}$ & Romã & Exotic & SDTF & $\begin{array}{l}\text { Bark, } \\
\text { Leaves, } \\
\text { Fruit \& } \\
\text { Seeds }\end{array}$ & $\begin{array}{l}\text { Throat } \\
\text { problems, } \\
\text { Stomach } \\
\text { problems \& } \\
\text { Inflammatio } \\
\text { n in general. }\end{array}$ & $\begin{array}{l}\text { Sterile } \\
\text { material }\end{array}$ \\
\hline \multirow[t]{2}{*}{ Rhamnaceae } & Ziziphus & $\begin{array}{l}\text { Ziziphus } \\
\text { joazeiro Mart. }\end{array}$ & Juazeiro & Native & $\mathrm{TR}$ & Bark & $\begin{array}{l}\text { Expectorant, } \\
\text { Toothache, } \\
\text { Flu \& colds, } \\
\text { Airway } \\
\text { inflammation } \\
\text { \& Cough. }\end{array}$ & $\begin{array}{l}\text { Sterile } \\
\text { material }\end{array}$ \\
\hline & & & & & SDTF & $\begin{array}{l}\text { Bark, } \\
\text { Leaves \& } \\
\text { Roots }\end{array}$ & $\begin{array}{l}\text { Expectorant, } \\
\text { Acariasis \& } \\
\text { other } \\
\text { infestations } \\
\& \text { Cough. }\end{array}$ & IPA91676 \\
\hline \multirow[t]{3}{*}{ Rubiaceae } & Borreria & $\begin{array}{l}\text { Borreria } \\
\text { verticillata (L.) } \\
\text { G. Mey. }\end{array}$ & $\begin{array}{l}\text { Vassoura } \\
\text { de botão }\end{array}$ & Native & $\mathrm{TR}$ & $\begin{array}{l}\text { Entire plant } \\
\text { or Roots }\end{array}$ & Stroke. & IPA91713 \\
\hline & Genipa & $\begin{array}{l}\text { Genipa } \\
\text { americana L. }\end{array}$ & Genipapo & Native & $\mathrm{TR}$ & $\begin{array}{l}\text { Bark \& } \\
\text { fruit }\end{array}$ & Anemia. & $\begin{array}{l}\text { Sterile } \\
\text { material }\end{array}$ \\
\hline & Tocoyena & $\begin{array}{l}\text { Tocoyena } \\
\text { formosa } \\
\text { (Cham. \& } \\
\text { Schltdl.) } \\
\text { K.Schum. }\end{array}$ & Genipapo & Native & SDTF & Bark & Stroke. & IPA91611 \\
\hline Rutaceae & Ruta & Ruta & Arruda & Exotic & SDTF & Leaves & Headache, & Sterile \\
\hline
\end{tabular}




\begin{tabular}{|c|c|c|c|c|c|c|c|c|}
\hline Family & Genus & $\begin{array}{l}\text { Medicinal } \\
\text { plants }\end{array}$ & $\begin{array}{l}\text { Common } \\
\text { name }\end{array}$ & Origin & $\underset{*}{\text { Region }}$ & $\begin{array}{l}\text { Part of the } \\
\text { plant used }\end{array}$ & $\begin{array}{l}\text { Therapeutic } \\
\text { indications }\end{array}$ & $\begin{array}{l}\text { Herbarium } \\
\text { voucher }\end{array}$ \\
\hline & & graveolens L. & & & & & $\begin{array}{l}\text { Pain in } \\
\text { general. }\end{array}$ & material \\
\hline Sapotaceae & Sideroxylon & $\begin{array}{l}\text { Sideroxylon } \\
\text { obtusifolium } \\
\text { (Roem. \& } \\
\text { Schult.) } \\
\text { T.D.Penn. }\end{array}$ & $\begin{array}{l}\text { Quixabeir } \\
\text { a }\end{array}$ & Native & SDTF & Bark & $\begin{array}{l}\text { Injury, } \\
\text { General } \\
\text { inflammation } \\
\text {, Stroke \& } \\
\text { Gynecologic } \\
\text { al problem. }\end{array}$ & $\begin{array}{l}\text { Sterile } \\
\text { material }\end{array}$ \\
\hline \multirow[t]{2}{*}{ Solanaceae } & Solanum & $\begin{array}{l}\text { Solanum } \\
\text { paniculatum L. }\end{array}$ & Jurubeba & Native & SDTF & $\begin{array}{l}\text { Leaves, } \\
\text { fruit, roots } \\
\& \text { Seeds }\end{array}$ & $\begin{array}{l}\text { Injury, } \\
\text { Stomach } \\
\text { problems, } \\
\text { Flu \& colds, } \\
\text { Inflammatio } \\
\text { n in general } \\
\text { \& Cough. }\end{array}$ & IPA91633 \\
\hline & & & & & TR & $\begin{array}{l}\text { Bark, } \\
\text { Flower, } \\
\text { Leaves, } \\
\text { Fruit, } \\
\text { Entire } \\
\text { Plant, } \\
\text { Roots, } \\
\text { Sap/Resin } \\
\text { \& Seeds }\end{array}$ & $\begin{array}{l}\text { Expectorant, } \\
\text { Flu \& colds } \\
\text { \& Cough. }\end{array}$ & IPA91709 \\
\hline Violaceae & Pombalia & $\begin{array}{l}\text { Pombalia } \\
\text { arenaria (Ule) } \\
\text { Paula-Souza }\end{array}$ & Papaconha & Native & SDTF & $\begin{array}{l}\text { Bark \& } \\
\text { Roots }\end{array}$ & $\begin{array}{l}\text { Expectorant, } \\
\text { Flu \& colds, } \\
\text { Airways } \\
\text { Inflammatio } \\
\text { n \& Cough. }\end{array}$ & IPA91628 \\
\hline
\end{tabular}




\section{Table 3 (on next page)}

Equivalence without pairs of the same species: results of the odds ratio test that verified whether pairs formed by plants of the same genus or of the same family are more likely to be Utility Equivalents.

The variables are organized as: total pairs of the same genus; equivalent pairs of the same genus; total pairs of different genera; equivalents of different genera; total pairs of the same family; pairs equivalents of the same family; total pairs of different families; equivalents of different families. In the OR column, the values of association between the variables (genus and family) and equivalence are indicated; In column \% the proportion of pairs that are and that are not formed by species of the same genus and family are indicated; In the IC column, the confidence intervals for OR values are indicated; In column $p$, the values of significance are indicated, values $<0.05$ being indicative that the results obtained were not by chance. 
1 Table 3. Equivalence without pairs of the same species: results of the odds ratio test 2 that verified whether pairs formed by plants of the same genus or of the same 3 family are more likely to be Utility Equivalents.

4

$\begin{array}{lllllll}\begin{array}{l}\text { Variables* } \\ (\mathbf{n}=2268)\end{array} & \text { Total } & \text { Equivalents } & \% & \text { OR } & \text { IC 95\% } & \text { p }\end{array}$

\begin{tabular}{lccrrrr}
\hline Genus & & & & & & \\
\hline Equal & 6 & 2 & 33.3 & 9.25 & $1.68-51.02$ & $<0.01$ \\
\hline Different & 2262 & 116 & 5.1 & & & \\
\hline Family & & & & & & \\
\hline Equal & 100 & 9 & 9.0 & 1.87 & $0.92-3.80$ & 0.0804 \\
\hline Different & 2168 & 109 & 5.0 & & & \\
& & & & & & \\
\hline
\end{tabular}

*The variables are organized as: total pairs of the same genus; equivalent pairs of the same genus; total pairs of different genera; equivalents of different genera; total pairs of the same family; pairs equivalents of the same family; total pairs of different families; equivalents of different families. In the OR column, the values of association between the variables (genus and family) and equivalence are indicated; In column \% the proportion of pairs that are and that are not formed by species of the same genus and family are indicated; In the IC column, the confidence intervals for OR values are indicated; In column $\mathrm{p}$, the values of significance are indicated, values $<0.05$ being indicative that the results obtained were not by chance. 


\section{Table 4 (on next page)}

Equivalence with pairs of the same species: results of the odds ratio test that verified whether pairs formed by plants of the same genus or of the same family are more likely to be Utility Equivalents.

The variables are organized as: total pairs of the same genus; equivalent pairs of the same genus; total pairs of different genera; equivalents of different genera; total pairs of the same family; pairs equivalents of the same family; total pairs of different families; equivalents of different families. In the OR column, the values of association between the variables (genus and family) and equivalence are indicated; In column \% the proportion of pairs that are and that are not formed by species of the same genus and family are indicated; In the IC column, the confidence intervals for OR values are indicated; In column $p$, the values of significance are indicated, values $<0.05$ being indicative that the results obtained were not by chance. 
1

2

3

4

5

6

7

Table 4. Equivalence with pairs of the same species: results of the odds ratio test that verified whether pairs formed by plants of the same genus or of the same family are more likely to be Utility Equivalents.

$\begin{array}{lllllll}\begin{array}{l}\text { Variables* } \\ (n=2268)\end{array} & \text { Total } & \text { Equivalents } & \% & \text { OR } & \text { IC 95\% } & \text { p }\end{array}$

\section{Genus}

\begin{tabular}{lccrrrr} 
Equal & 18 & 7 & 38.9 & 11.77 & $4.48-30.93$ & $<0.0001$ \\
\hline Different & 2262 & 116 & 5.1 & & &
\end{tabular}

\section{Family}

\begin{tabular}{lcccccc}
\hline Equal & 112 & 14 & 12.5 & 2.7 & $1.49-4.88$ & $<0.001$ \\
\hline Different & 2168 & 109 & 5.0 & & & \\
\end{tabular}

\footnotetext{
*The variables are organized as: total pairs of the same genus; equivalent pairs of the same genus; total pairs of different genera; equivalents of different genera; total pairs of the same family; pairs equivalents of the same family; total pairs of different families; equivalents of different families. In the OR column, the values of association between the variables (genus and family) and equivalence are indicated; In column \% the proportion of pairs that are and that are not formed by species of the same genus and family are indicated; In the IC column, the confidence intervals for OR values are indicated; In column $\mathrm{p}$, the values of significance are indicated, values $<0.05$ being indicative that the results obtained were not by chance.
} 


\section{Table 5 (on next page)}

Results of the odds ratio test that verified whether pairs formed by plants of the same genus or the same family are more likely to be Utility Redundants.

The variables are organized as: total pairs of the same genus; equivalent pairs of the same genus; total pairs of different genera; equivalents of different genera; total pairs of the same family; pairs equivalents of the same family; total pairs of different families; equivalents of different families. In the OR column, the values of association between the variables (genus and family) and equivalence are indicated; In column \% the proportion of pairs that are and that are not formed by species of the same genus and family are indicated; In the IC column, the confidence intervals for OR values are indicated; In column $p$, the values of significance are indicated, values $<0.05$ being indicative that the results obtained were not by chance. 
1 Table 5. Results of the odds ratio test that verified whether pairs formed by plants of 2 the same genus or the same family are more likely to be Utility Redundants.

3

$\begin{array}{lllllll}\begin{array}{l}\text { Variables* } \\ (n=2473)\end{array} & \text { Total } & \text { Redundants } & \% & \text { OR } & \text { IC 95\% } & \text { p }\end{array}$

\section{Genus}

\begin{tabular}{lcccccc}
\hline Equal & 9 & 1 & 11.1 & 2.21 & $\begin{array}{l}0.27- \\
17.79\end{array}$ & 0.4451 \\
\hline Different & 2464 & 132 & 5.4 & & &
\end{tabular}

\section{Family}

\begin{tabular}{lllcccc}
\hline Equal & 137 & 13 & 9.5 & 1.94 & $\begin{array}{c}1.06-3- \\
53\end{array}$ & $<0.05$ \\
\hline
\end{tabular}

Different

2336

120

5.1

*The variables are organized as: total pairs of the same genus; equivalent pairs of the same 5 genus; total pairs of different genera; equivalents of different genera; total pairs of the 6 same family; pairs equivalents of the same family; total pairs of different families; 7 equivalents of different families. In the OR column, the values of association between the 8 variables (genus and family) and equivalence are indicated; In column \% the proportion of 9 pairs that are and that are not formed by species of the same genus and family are indicated;

10 In the IC column, the confidence intervals for OR values are indicated; In column $p$, the 11 values of significance are indicated, values $<0.05$ being indicative that the results obtained 12 were not by chance. 